\title{
Identity and Power Relationship in The Mimic Men
}

\author{
Aoran Zhang \\ School of Foreign Languages and Cultures, Nanjing Normal University, Nanjing 210000, China \\ 3330215808@qq.com
}

\begin{abstract}
In the post-colonial era, people in the third world experienced the process of the dissolution of their national culture and the establishment of colonized culture. They gradually lost their identity in the cultural hegemony and felt confused and helpless about their identity. Against the background of post-colonial era, V.S. Naipaul's The Mimic Men not only shows the political, social, cultural and psychological impact of colonization on local people, but also the identity confusion of colonial people. This paper aims to analyze "identity" and "power relationship", which is based on the descriptions of characters and their psychology in The Mimic Men.
\end{abstract}

Keywords: Post Colonialism, Identity, Power Relationship.

\section{Introduction}

The Mimic Men is a post-colonial novel about the memoir of the narrator Ralph Singh's life in island of Isabella (a Caribbean island colonized by Britain) and London. The book describes how he grows up under the influence of British colonial culture, deals with mixed culture, loses himself and then embarks on the journey of identity inquiring and root searching in exile in London.

After the World War II, the independence movement of colonies rose. People in colonies demanded economic, political and even cultural independence. Maybe under this global atmosphere, Naipaul wrote this book which was published in 1967. In addition, Naipaul himself was born in a colonial island and then settled in Britain. Thus, he shares the same feeling with colonized people with double identity and identity confusion. The content of this book is partly similar to his real life experience in Trinidad. Today, in this world, there are still a variety of occupied colonies. Numbers of people are suffering the miserable situation of identity inquiring and root searching.

\section{Identity in The Mimic Men}

As a post-colonial work, this book gives readers a sense of homelessness because the narrator Ralph Singh lost in his double identity and tried to attain his self-identity again. However, what is identity? In fact, identity grows from collective group consciousness that gives a sense of belonging derived from membership in a community bound by common descent and culture. As a phenomenon, it gives the individual a sense of belonging and to the community a sense of solidarity (Asangaeneng, Udoette, 2019). But for the colonial people, their original national culture and society were ruined by those of colonizer's. Thus, the colonized seek their identity and try to establish order in the mixed culture when trapped in the mimicry relationship between colonies and Britain.

The book begins with the displaced narrator Ralph Singh wandering in London in a rental house owned by Shylock, a British old gentleman. In the beginning of the book, the mimicry occurs between Singh and Mr. Shylock. "And for Mr. Shylock... and of suits made of clothes so fine I felt I could eat it, I had nothing but admiration... and I thought Mr. Shylock looked distinguished, like a lawyer or businessman or politician...I thought the gesture was attractive." (The Mimic Men, 9) He admires not so much him as Britain's integrated culture. As a dislocated colonial minister in exile, he is eager for identity. As Cudjoe said in his book, "He both recognizes and criticizes colonial mimicry, but he also knows that he cannot help being a mimic man as he is a specific product of a particular socioeconomic formation called colonialism." (Selwyn R, 1988) Actually, Singh is the representative of displaced individuals. Britain's colonization has already taken away his original history, language, culture, nation, and identity (Asangaeneng, Udoette, 2019).

\section{The Complex Relationship Between Colony and Britain}

In the memoir, the author focuses on Singh's marriage and relationship with Sandra, his wife who goes back to Isabella with him later. Detailed descriptions of sex appear frequently in the novel. The relationship between Singh and Sandra is like the one between the colony Isabella and Britain. The unequal sex relationship not only represents sex itself, but also the power between the strong and the weak, which symbolizes the relationship between the Colony and Britain. In essence, they use each other to achieve their own goals. "She would overwhelm me now. I know her looks were of the sort that improves with the strength and definition of maturity." (The Mimic Men, 39) As a white Englishwoman, Sandra is still superior for her race in Isabella even though she is not in a good situation in her motherland, which is a proof of the importance of origin. Singh is fascinated by her at first, but loses the interest in the end, which means that he finally breaks the illusion about seeking identity through mimicry. Singh's conquest of Sandra (through marriage or sex) is actually an effort to prove his identity, aiming to gain the same status as the colonists. This also shows his acquiescence to his "other" status.

In the book, Naipaul elaborates in detail the influence of the original suzerain. It is like a huge black hand behind the scenes to manipulate the lives of newly independent people (Luo, 2002). Singh cannot resist the unseen influence from British colonization, so he can just conquer Sandra in sex to express his revolt. But all his revolt and resistance are in vain. He cannot become an Englishman unless he was born in England. Singh is aware of his two sides: he is both English and Caribbean. There are two souls, two thoughts, two 
conflicting forces and two contradictory ideals in the same body. But sadly, he does not completely belong to either of the two identities. For the difference of geographical environment, politics, culture and society, colonialists assume that human biological and physical characteristics are eternal racial "tattoos", which inevitably distorts or erases the history and culture of colonized races. Colonialists boast themselves as representatives of civilization and progress and "reasonable and legal" guardians of backward nationalities (Tao, 2004).

In the later chapter, Singh recalls his childhood and his political experience. He meets the mixed culture, puzzled to seek his original identity. Seeing the disorderly Isabella, he tries to change the situation but finally fails. "Having no gifts to offer, they seldom know what they seek. They might say they seek power. But their definition of power is vague and unreliable." (The Mimic Men, 37) Although Isabella is independent, it is still invisibly influenced by Britain. Colonists do not give colonized people an opportunity to cultural control. They force the other to accept a certain designated identity. Moreover, it is the power relationship that determines a person's social identity or any kind of identity. In the history of colonialism and imperialism, Europe undoubtedly represents power. In the Caribbean region, it always exists in the dialogue of resistance, rejection and recognition of the colonized to European colonists. Its influence is irreversible, and so is its internalized education. Therefore, it has played an inestimable role in the formation of identity. Unless through "imaginary geography and history", it is impossible to return to the original identity for the colonized (Chen, 2016).

Military power has gone, but cultural power from Britain still exists. In the process of colonization, language and weapons are powerful tools to destroy national culture, especially language. It plays a strong role in disintegrating the traditional culture of the colony. As the carrier of colonists' cultural values, language can corrode and completely destroy another culture from the bottom, which leads to the disappearance or fading of the traditional culture of a nation on the historical stage (Ren, 2003). As a politician in London, if Singh wants to regain the identity, he would first establish their own language, politics and culture, but the fact is that the system of their nation is affiliated to that of super-powers. Therefore, he cannot find his original culture back. In that case, it is impossible to reestablish their nationality. With no independent language, there is no culture, no nation. To maintain a nation, culture is indispensable, which make colonial people go into a desperate and helpless situation.

\section{Conclusion}

The Mimic Men fully describes the process of how people in the Caribbean seek their identity after independence. It accurately shows the power relationship between the colonies and the suzerain of "imitate and imitated", "ruled and rule". Through this book, readers can penetrate the detailed life of people who live in a post-colonial country and share the feeling with them. The double identity, homelessness, rootlessness, confusion, and displacement haunt in the mind of those who are in the same situation like Ralph Singh. At the end of this book, Naipaul does not tell his readers how to deal with "double identity" and "rootlessness", which calls for imagination, thinking, and reflection on dealing with this problem closely related to a large number of people in this world.

In general, The Mimic Men represents the life of colonized people. More importantly, it shows readers the psychological pain caused by identity confusion. For colonized people, independence movement is important, but more importantly, after the liberation from super-powers, how to reestablish the original culture and politics, how to find the identity back, and how to escape from the invisible control of colonization are the main problems that need to be solved immediately.

\section{References}

[1] Cudjoe, Selwyn R. V. S. Naipaul: A Materialist Reading. Amherst: The University of Massachusetts Press, 1988.

[2] Chen Yongguo. Identity Recognition and the Politics of Literature. Journal of Tsinghua University (Philosophy and Social Sciences), 2016, 31(06): 22-31+192.

[3] Joseph Asangaeneng, Monica Udoette. The Politics of Home and Identity in V.S. Naipaul's The Mimic Men. AFRREV IJAH: An International Journal of Arts and Humanities, 2019, 8(1): 56-65.

[4] Luo Xiaoyun. Analysis of Naipaul's post-colonial consciousness from The Mimic Men. Foreign Language and Literature, 2002(06): 42-45.

[5] Ren Yiming. "Exile" and "Root Seeking"_- The Writing Language of English Postcolonial Literature. Comparative Literature in China, 2003(02): 162

[6] Tao Jiajun. Introduction to identity. Foreign Literature, 2004(02):41

[7] Vidiadhar Surajprasad Naipaul. The Mimic Men. Vintage Books, New York, USA, 1967. 